\title{
The Excavation of a Mound and Three Cist Burials at Ferndale, Rendall, Orkney
}

\author{
by Paul R J Duffy \\ GUARD, Gregory Building, Lilybank Gardens, \\ University of Glasgow, Glasgow G12 8QQ \\ with contributions by \\ Bob Will, Caitlin Evans, Jennifer Miller, \\ Susan Ramsay, Gavin MacGregor and Tony Pollard \\ Illustrations by Gillian McSwan, \\ Caitlin Evans and Jill Seivewright
}

Scottish Archaeological Internet Report 16, 2005 www.sair.org.uk 
Published by the Society of Antiquaries of Scotland, www.socantscot.org with Historic Scotland, www.historic-scotland.gov.uk and the Council for British Archaeology, www.britarch.ac.uk

Editor Debra Barrie

Produced by Archetype Information Technology Ltd, www.archetype-it.com

ISBN: 0903903857

ISSN: $1473-3803$

Requests for permission to reproduce material from a SAIR report should be sent to the Director of the Society of Antiquaries of Scotland, as well as to the author, illustrator, photographer or other copyright holder.

Copyright in any of the Scottish Archaeological Internet Reports series rests with the SAIR Consortium and the individual authors.

The maps are reproduced from Ordnance Survey material with the permission of Ordnance Survey on behalf of The Controller of Her Majesty's Stationery Office. (CCrown copyright 2001. Any unauthorized reproduction infringes Crown copyright and may lead to prosecution or civil proceedings. Historic Scotland Licence No GD 03032G, 2002.

The consent does not extend to copying for general distribution, advertising or promotional purposes, the creation of new collective works or resale. 


\section{Contents}

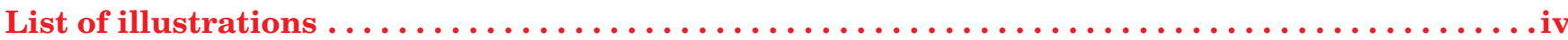

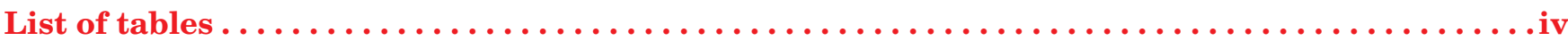

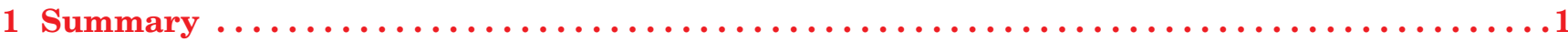

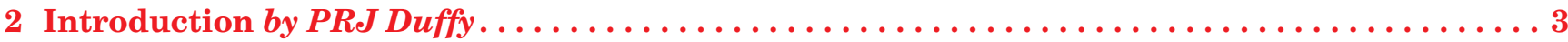

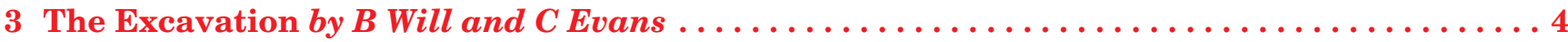

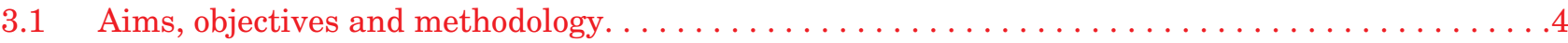

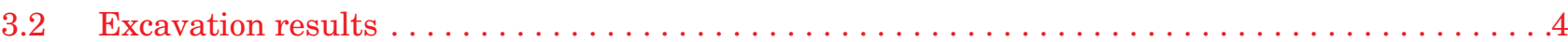

4 The Human Remains from the Cists by PRJ Duffy $\ldots \ldots \ldots \ldots \ldots \ldots \ldots \ldots \ldots \ldots \ldots \ldots$

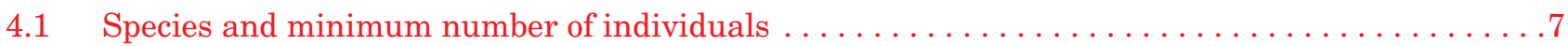

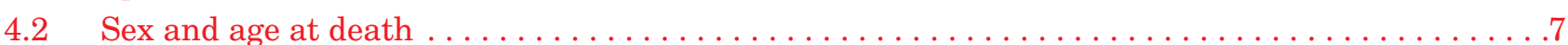

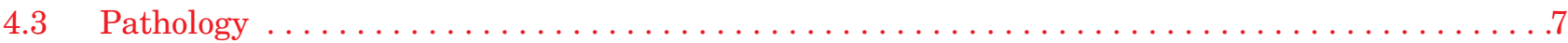

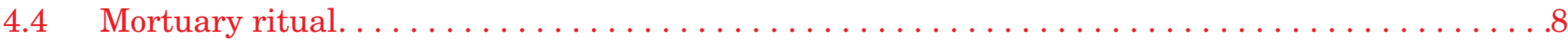

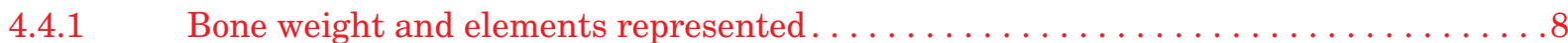

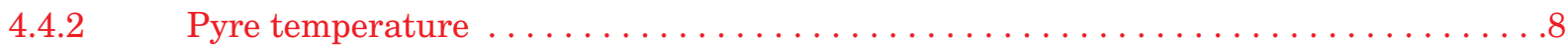

5 Charcoal and Carbonized Plant Remains by J Miller and $S$ Ramsay ................. 9

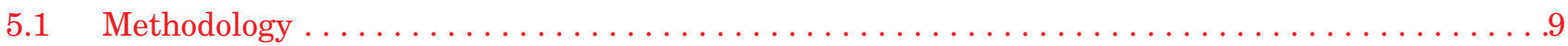

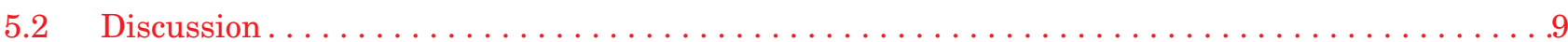

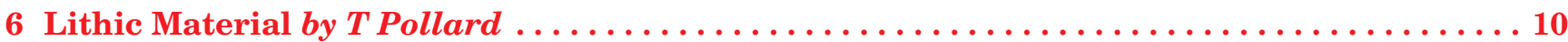

$6.1 \quad$ Results. . . . . . . . . . . . . . . . . . . . . . . . . . . . . . . . . . . 10

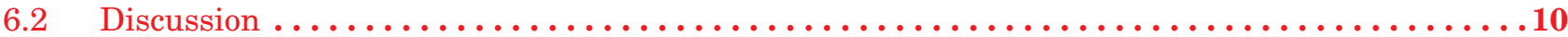

7 Megalithic Art on the Ferndale Slab by G MacGregor ..................... 11

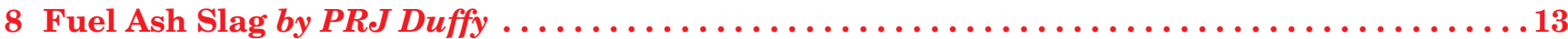

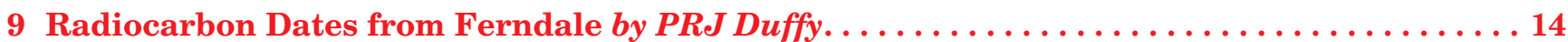

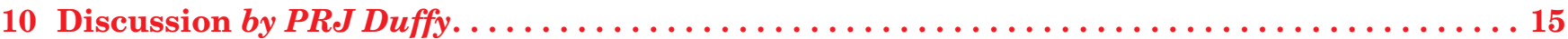

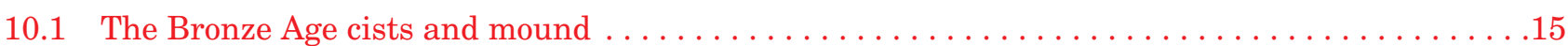

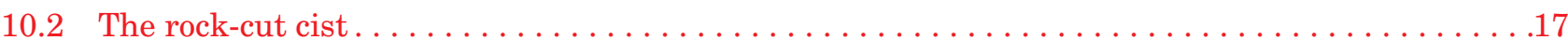

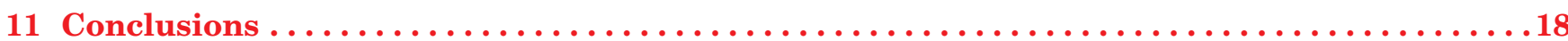

12 Acknowledgements ................................................... 19

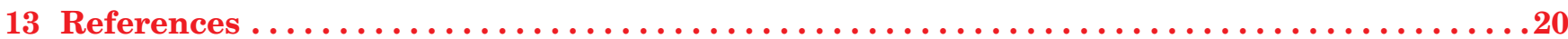




\section{List of illustrations}

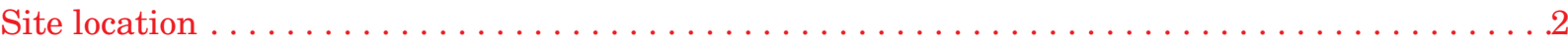

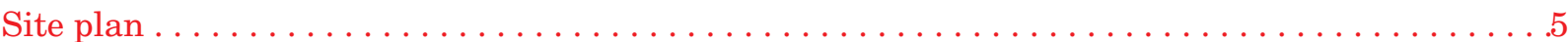

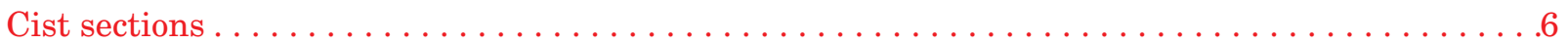

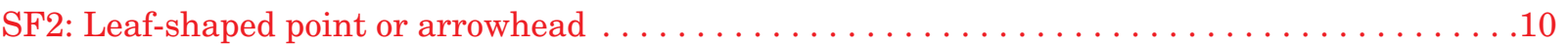

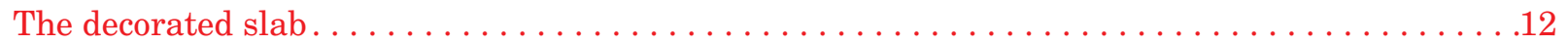

\section{List of tables}

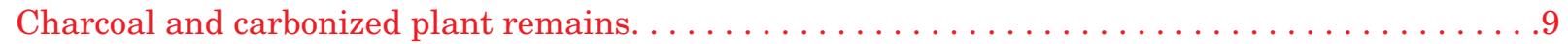

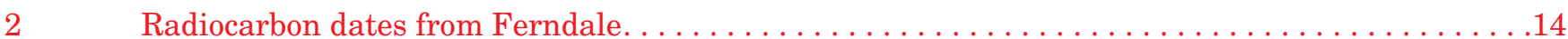

3 Summary of radiocarbon dates from cists in Orkney containing cremations . . . . . . . . . 15 


\section{Summary}

As part of the Historic Scotland Human Remains Call Off Contract, Glasgow University Archaeological Research Division (GUARD) undertook an archaeological excavation of an artificial mound and associated cists containing human remains of mid-Bronze Age date, at Ferndale, Rendall, Orkney (Illus 1). The excavation identified the presence of two cists containing cremation burials (cist 004 and cist 010), and a third that contained a poorly preserved inhumation (cist 003). Cists 004 and 010 would appear to be related to an artificially created mound, and parallel a number of similar 'barrow' sites from Orkney. Cist 004 contained an inhumation and was of differing construction. It would appear to relate to a different phase and tradition of cist burials.

Analysis of skeletal material from cist 004 identified the remains of an older adult male, a female of between 18 and 30 years of age and an infant of 15 months. The adult male was found to have suffered from a bone infection of the femur and showed evidence of poor dental health. The female had suffered from iron deficiency anaemia. The preservation of skeletal material in cists 010 and 003 allowed only the identification of a single adult inhumation of unknown age and sex from each cist. The individuals from cists 004 and 010 had been cremated shortly after death, and analysis of associated soil residues suggests that their remains were subsequently picked from the pyre and washed.

Radiocarbon dates from the cremated remains from cists 004 and 010 place the use of these two cists and construction of the associated mound in the first quarter of the second millennium BC. These dates are comparable to other dated cist burials in artificial mounds from Orkney, although it would appear to be one of the earlier sites in the currently available list of dates. Regrettably, a date could not be obtained from the poorly preserved inhumation from cist 003. 

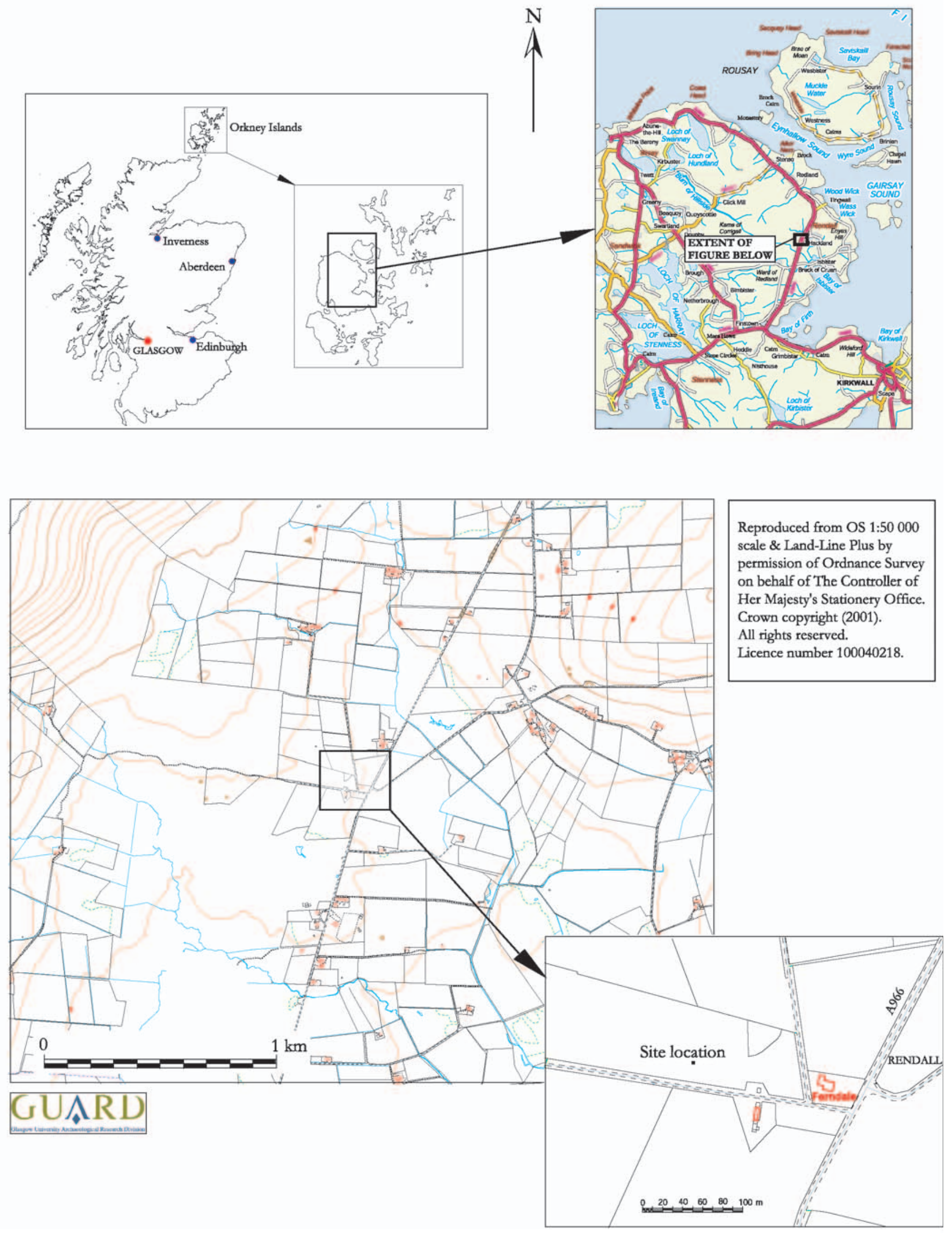

Illus 1 Site location 


\section{Introduction by PRJ Duffy}

The site was discovered by $\mathrm{Mr} \mathrm{S}$ Nicholson, of Gitterpitten, Rendall, during ground levelling works by machine, intended to flatten a small knoll in the field. The presence of small quarry pits in the immediate vicinity had initially led the farmer to believe that the visible portions of the artificial mound were a stone dump or quarry site. Shortly after the works started it became apparent that the knoll might instead be a burial mound. The discovery was promptly reported to Julie Gibson of Orkney Archaeological Trust (OAT) who undertook a preliminary site inspection. This inspection verified the presence of a cist containing substantial quantities of cremated human bone, and identified a deposit of fuel ash slag and cremated material spread by machine disturbance from a second collapsed cist. The discovery was reported to Historic Scotland and an archaeological excavation was undertaken at the site of the find spot over 7 days during June 2003, as part of the Historic Scotland Human Remains Call Off Contract.

Ferndale Farm is located at the eastern side of the Orkney Mainland within the parish of Rendall. The site is situated on the east-facing slopes of a field of improved pasture, to the west of the A966 (NGR HY 3836 2035). The area is characterized by gently sloping fields of improved pasture within a shallow valley, bounded by low rolling hills broken to the south-east, with views across Wide Firth to Kirkwall. Within the field, a large quarry pit to the north-east of the site and the other small quarry pits or dumps within the field boundary attest to a history of stone extraction in the area.

The specialist reports below are edited versions of the full texts, which form part of the site archive. The site archive will be deposited with the National Monuments Record of Scotland, RCAHMS, Edinburgh. 


\section{The Excavation by $B$ Will and $C$ Evans}

\subsection{Aims, objectives and methodology}

The primary objectives of the excavation were to establish whether human remains were present within the cists, the state of preservation of any such remains and how they had been deposited. The secondary objectives were to establish whether there were any intimately related structures in the vicinity of the site, and fully to record and recover any human remains and associated structures up to an area of $40 \mathrm{~m}^{2}$ or, in the event of multiple burials, to consult with Historic Scotland and the Regional Archaeologist to establish a suitable mitigation strategy.

On arrival, the condition of the site was assessed and recorded photographically. An area $10 \mathrm{~m}$ by $10 \mathrm{~m}$ was cordoned off and, within that, an area of $9.2 \mathrm{~m}$ east/west by $6.8 \mathrm{~m}$ north/south was handexcavated through the topsoil layer to reveal the extent of the remnant mound and associated cists. All contexts containing human remains were $100 \%$ sampled. Selective bulk sampling of additional archaeologically significant contexts was also undertaken. On completion of the excavation, cist 003 was backfilled using the larger stones from cist 004 and the base slab of cist 010. Cist 004 was dismantled and the extant mound material excavated to the level of the rest of the surrounding material. Geotextile was placed over the remains of the mound and the whole site backfilled, affording preservation of the remnants of the site in situ (see Illus 2).

\subsection{Excavation results}

Very little of the mound (014) remained, with only the eastern side partly surviving next to a stone built cist (004) which stood proud of the surrounding mound matrix (Illus $3, \mathrm{~A}-\mathrm{A}^{\prime}$ ). This cist sat in a cut (029) measuring $2.4 \mathrm{~m}$ east/west by $1.1 \mathrm{~m}$ north/ south excavated through the underlying old ground surface (026). Four regular sub-rectangular slabs formed the cist walls, which were surrounded with packing stones (030) on all sides. One of these packing stones had evidence of some surface decoration (see Section 7 - Megalithic Art on the Ferndale Slab). The cist contained a deposit of well-preserved cremated human remains (008) and a loose, light to mid brown silt clay (009) and was sealed with a single capping stone (007) (Illus 3 , B-B'). The cist was orientated north-east/ south-west and measured $0.7 \mathrm{~m}$ north-east/south west by $0.5 \mathrm{~m}$ north-west/south-east. At the southwest end, beyond the cut and within the mound material, a layer of dark brown clay silt with frequent charcoal flecks and angular gravel (024) was recorded.

Immediately to the south and west of cist 004 was a spread of peat-rich silt, boulder clay and grits mixed with fuel ash slag (cramp) and cremated bone (006). The deposit was very disturbed, and machine bucket marks were observed at the western extent of the material. Removal of the entire deposit revealed the base slab and fragments of the north and south sides of a second cist (010), orientated north-east/south-west and measuring $1.2 \mathrm{~m}$ by $0.6 \mathrm{~m}$. Remnants of the original ground surface (026) were also observed at this time. Excavation revealed this cist sat in a cut (011), the size of which was not discernible due to machine disturbance, and which was excavated through the old ground surface (026). A deposit of brown-yellow sandy clay (012) was packed between the surviving cist walls and the edges of the cut. Removal of the cist base revealed a layer of compact yellow clay with angular gravel (027) above an original ground surface (028), similar to context 026 .

Immediately to the west of these two cists, a third structure (003) was examined (Illus 3, C-C' \& D-D'). This cist was inserted into a cut excavated directly in the bedrock (021), which defined an area of approximately $2.20 \mathrm{~m}$ by $1.60 \mathrm{~m}$ orientated north-east/ south-west. The east and west sides of the cist appeared to have been damaged, while the northern side was missing. Removal of the loose capping stones (005) revealed a brown-yellow sandy clay with lenses and lumps of dark brown clay silt (015). Underlying this deposit were the badly decayed remains of an inhumation contained within a layer of moderately compact yellow-brown sandy clay with frequent fragments and chips of stone and small lumps and lenses of grey-brown clay silt (016). On the west side the damaged side slab was supported by roughly coursed stone work to the north and south which formed a sub-rectangular space measuring $0.44 \mathrm{~m}$ by $0.61 \mathrm{~m}$ and $0.51 \mathrm{~m}$ deep (context 019) (Illus 3, E-E'). This space or box appeared to have been an attempt to create a construction stance and was subsequently filled with a mixture of yellow-brown clay silt with frequent stone flakes and chips (context 018). The interface between the two was stained darker with silt brought in through water infiltration. The cist space to the east of this stance measured $1 \mathrm{~m}$ north-east/ south-west by $0.75 \mathrm{~m}$ north-west/south-east. Due to machine damage to the mound, the relationship between this cist and the other two structures was not discernible. 


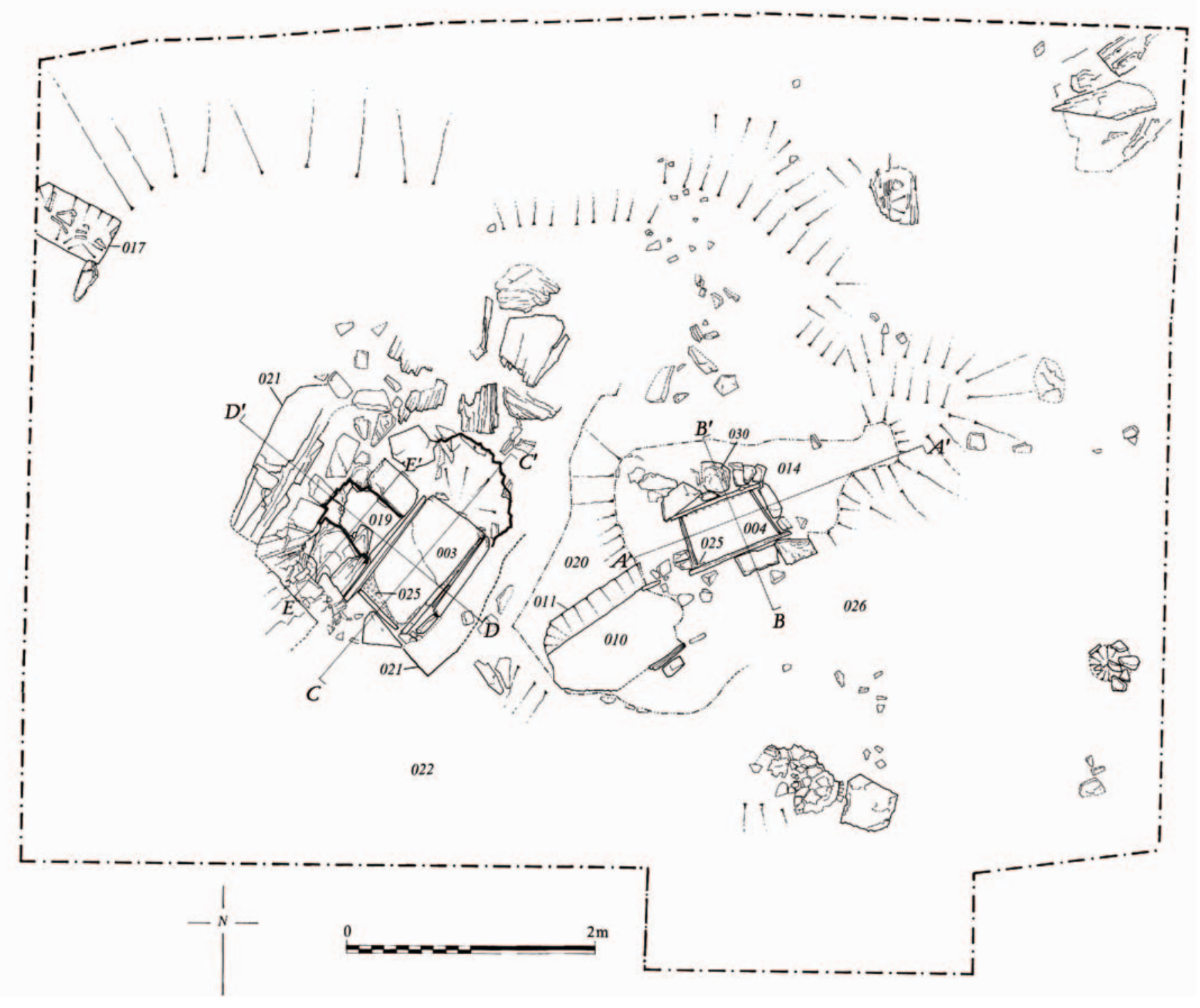

Illus 2 Site plan 

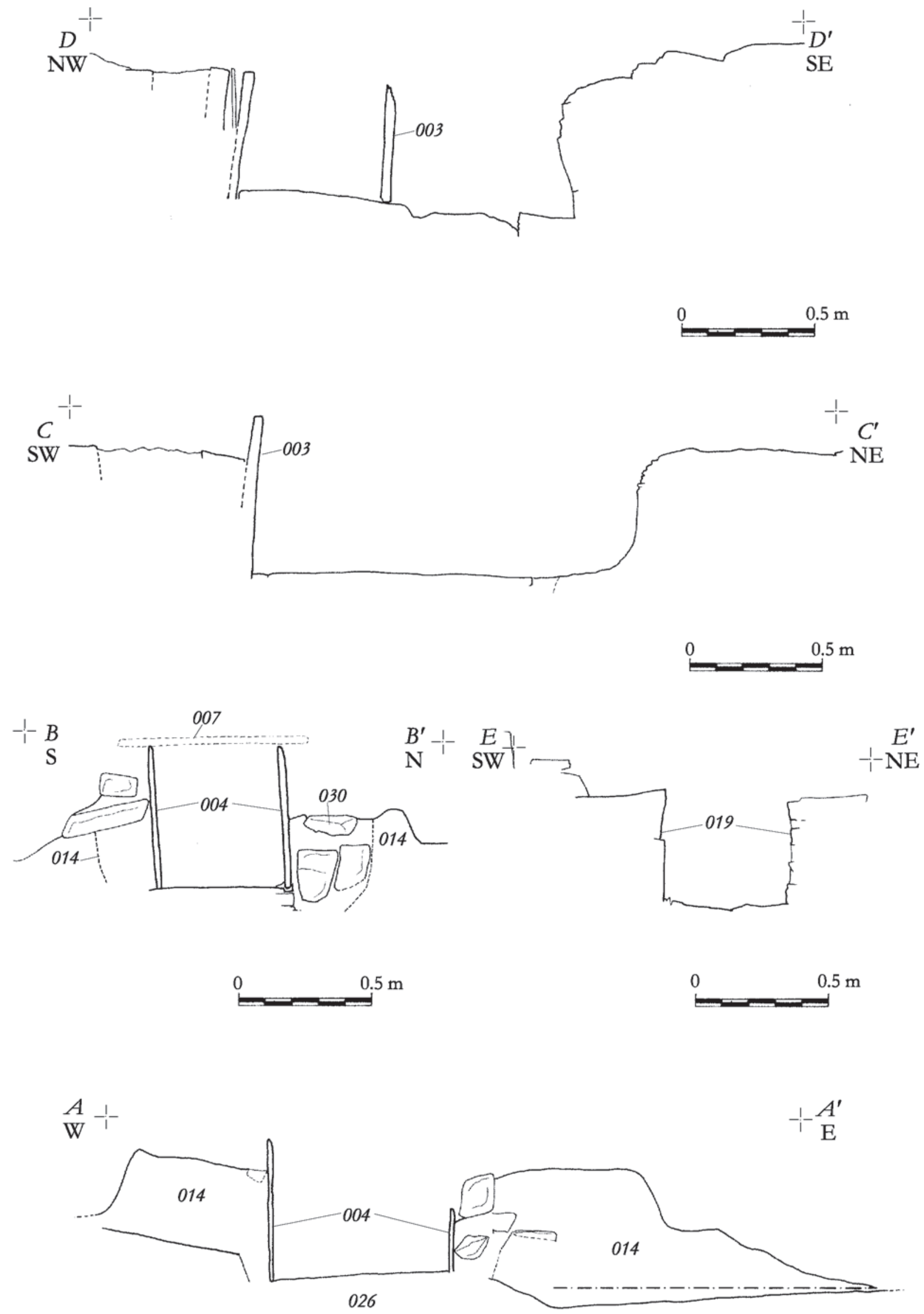

Illus 3 Cist sections

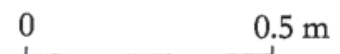




\section{The Human Remains from the Cists by PRJ Duffy}

Each context containing cremated bone was initially sieved using $10-\mathrm{mm}$ and $4-\mathrm{mm}$ meshes and subsequently sorted from other materials. The amount of bone within the $>10 \mathrm{~mm}$ fraction and the $4-10 \mathrm{~mm}$ fraction was weighed, analysed and recorded in a skeletal inventory. The proportion of identified and unidentified elements within each fraction was recorded. Fragments were termed unidentified if they could not be ascribed to a specific element or body area. Bone measuring less than $4 \mathrm{~mm}$ in diameter was examined and weighed, but only recorded if diagnostic fragments of bone or dentition could be identified.

The preservation of the cremated remains from Ferndale was generally good. Most of the fragments were greater than $10 \mathrm{~mm}$ in diameter, and had suffered little surface erosion. Thus a large percentage of the bone, predominantly from the $>10 \mathrm{~mm}$ fraction, could be identified.

The preservation of the inhumed remains from cist 003 was poor, with much of the bone highly degraded and fragmented. This appeared to be due mainly to the preservation conditions within the cist itself. The poor preservation of the uncremated remains recovered from cist 003 necessitated the lifting of the skeletal material as block samples. The post-excavation analysis thus consisted of an initial sorting of this material by hand from the surrounding soil matrix. Elements present were then recorded on a standard skeletal pro forma recording sheet.

\subsection{Species and minimum number of individuals}

All of the bone from the cists was human. A minimum of three individuals were identified from the cremated remains in cist 004 , through repeated elements of the sciatic notch of the illium and the proximal head of the right ulna. A minimum of one individual was identified from both cist 003 and cist 010 .

\subsection{Sex and age at death}

Sexually dimorphic elements were sufficiently preserved from the assemblage recovered from cist 004 to allow the identification of an adult male, an adult female and an infant through morphological characteristics of the occipital nuchal crest, sciatic notch of the illium, ischial tuberosity and longbone thickness.
Based on the state of epiphysial fusion of the skeletal elements associated with the female individual, particularly an unfused gracile clavicle, an age of $c$ 18-30 years is suggested. The adult male proved more difficult to age, with few diagnostic indicators identified. However, several fragments of robust cranial elements with partially fused suture lines were identified. Although rates of cranial suture closure vary among individuals, this may be used as a guide that the individual was probably closer to middle age than a younger individual. Age at death was more straightforward to establish for the infant. The dental development of two deciduous molars indicated the infant was $c 15$ months at death (Moorress et al 1964).

The lack of diagnostic elements for bone recovered from cist 010 prevented the identification of age or sex, beyond that of an adult, based on the morphological characteristics of the bone examined. Similarly, the poor preservation of the skeletal elements from cist 003 meant that the individual could not be assigned a biological sex or age at death, beyond the attribution of adult.

\subsection{Pathology}

Examination of the well-preserved remains from cist 004 revealed a number of pathological conditions. An externally draining dental abscess was identified on the male maxilla at the position of the left second premolar. The infection had also led to breaching of the thin wall of bone which separates the maxillary sinus cavity from the alveolar process of the upper jaw; this would undoubtedly have been a painful condition. Severe pitting of the palatine surface was also observed in the same individual. Such changes have been linked to a number of infectious and metabolic diseases, including leprosy and scurvy (Aufterheide \& Rodriguez-Martin 1998). However, in the absence of any other skeletal indicators, a diagnosis of the causes of this condition cannot be made accurately.

Osteitis, or inflammation of the cortical bone, was identified on two fragments of male femur. Characterized by a thickening of the cortical (outer) layer of bone and an associated reduction of the medullary (inner) cavity, osteitis can occur as a result of bacterial infection of the bone matrix itself. The condition can have many causes, including traumatic injury and disease conditions, and is likely to have caused some discomfort.

Iron deficiency anaemia was evident, characterized by porotic hyperostosis (a pitting and thickening of the middle layer of the skull) and cribra orbitalia 
(a pitting of the superior eye orbits). Three fragments of unsexed frontal bone displayed changes consistent with porotic hyperostosis, and one fragment of female frontal displayed changes consistent with stage 1 cribra orbitalia (Stuart Macadam 1992). There are many causes of iron deficiency anaemia, amongst the most common being lack of absorbable iron in the diet and a high pathogen load within the body (Stuart Macadam 1992). Severe anaemia can cause fatigue and palpitations, leaving the affected individual weak and breathless. In this case, the manifestation was not severe and it is unlikely that she would have been debilitated by the condition.

A single unsexed distal hand phalange with pitting and osteophyte formation (bony outgrowths) was also recorded from the assemblage in cist 004. This can also be caused by a variety of conditions, including rheumatoid arthritis. Without further skeletal indicators as to the cause of this condition, diagnosis is elusive.

\subsection{Mortuary ritual}

\subsubsection{Bone weight and elements represented}

Cist 004 was found to contain the remains of three cremated individuals, weighing a total of $2496 \mathrm{~g}$; as such, it is not possible to speculate as to the relationship between bone weights and elemental representation among these individuals. The remains from cist 010 weighed a total of $230 \mathrm{~g}$, significantly less than that estimated for an adult male (2283.5g) or female (1615.7g) (McKinley 1993). Skeletal elements appeared limited to longbone, cranium and rib. Several reasons could explain this, including selective processes in collection from the pyre or deposition in the cist, or accidental factors such as spillage or post-depositional damage and destruction.

\subsubsection{Pyre temperature}

Distinct and consistent colour changes have been observed in heat-treated human bone and are white when all the organic matter is combusted and cremation is complete at temperatures in excess of $700-800^{\circ} \mathrm{C}$ (Shipman et al 1984; Holden et al 1995). The fragments from cist 004 at Ferndale ranged mainly from white through to yellow-white, indicating that the pyre technology and fuel sources employed were sufficient to create and sustain enough heat to cremate their dead fully. Notable exceptions to this pattern were a number of elements of the pelvis and lower limbs from the male individual. These varied in colour from grey to grey-black, demonstrating the incomplete combustion of the organic portion of the bone. Several factors, or combinations of factors, may be suggested to have caused this, including heavier musculature and/or body fat, position of the body on the pyre, insufficient fuel resources, or deliberate stoking and raking of the pyre during cremation. Evidence for this last factor may also be inferred from the differential colours of several of the cranial fragments identified during the analysis. It is possible that the cranium was fractured and those fragments that were grey in colour had been pushed to the peripheries of the pyre or had lain at the bottom in a layer of ash. The cracking patterns that were evident on many of the bones and the warpage of several of the larger fragments also indicate that the body had been cremated soon after death, while still fleshed (Ubelaker 1989, 36-38).

The cremated remains from cist 010 show little variation from a white to yellow-white colour, indicating the individual was fully cremated. Similar bone warpage as that described above again showed the body had been cremated while fleshed. 


\section{Charcoal and Carbonized Plant Remains by $J$ Miller and $S$ Ramsay}

\subsection{Methodology}

Identification of seeds and vegetative plant remains was undertaken with reference to Zadenatlas der Nederlandsche Flora (Beijerinck 1947). The internal anatomy of charcoal was identified with reference to Anatomy of European Woods (Schweingruber 1990). Vascular plant nomenclature follows New Flora of the British Isles (Stace 1997). Wherever it was not possible accurately to quantify elements within the samples, a scoring system of one to three plus marks was used denoting trace to abundant presence.

\subsection{Discussion}

The carbonized assemblage from Ferndale was sparse, containing only very small charcoal fragments (Table 1). Consequently, any conclusions drawn must necessarily be tentative. Cists 003 and 004 contained several charcoal types, including small trees and shrubs that would have been locally available, albeit not abundantly, in the Bronze Age. Small fragments of birch (Betula) and hazel (Corylus) charcoal within the cists suggests the utilization of either local scrub woodland or driftwood resources as fuel, although it is impossible to determine whether this is residual from domestic material or ritual fires. Further evidence for potential fuel sources is indicated by heather family (Ericaceae) charcoal, burnt monocot type (grass/ sedge) stems/rhizomes and occasional seeds of grassland indicators in cists 003 and 010 . Together, these remains may be indicative of turf as fuel, or the construction of a fire (or pyre) over heathy grassland.

Occasional fragments of carbonized brown (Fucoid) seaweed were also recovered from cists 003 and 010 . Seaweed has been used as fertilizer and domestic fuel since antiquity (Dickson \& Dickson 2000), especially in areas where other fuel resources are scarce. As cist 003 contained an inhumation, it would appear that either a cremation had also been in cist 003, or that contamination of the cist fills had occurred.

Food remains in the form of rare cereal grains including six-row barley (Hordeum vulgare sl) and hazel (Corylus avellana) nutshell - were the only evidence for human diet. These may be residual from a ritual feast or food offering, or from accidental incorporation of background domestic occupation debris into the cist deposits.

Table 1 Charcoal and carbonized plant remains

\begin{tabular}{|c|c|c|c|c|c|c|}
\hline & $\begin{array}{l}\text { Location } \\
\text { Context } \\
\text { Sample }\end{array}$ & $\begin{array}{l}\text { Cist } 10 \\
006 \\
001\end{array}$ & $\begin{array}{l}\text { Cist } 4 \\
009 \\
003\end{array}$ & $\begin{array}{l}\text { Cist } 4 \\
009 \\
004\end{array}$ & $\begin{array}{l}\text { Cist } 3 \\
016 \\
007\end{array}$ & $\begin{array}{l}\text { Cist } 3 \\
018 \\
009\end{array}$ \\
\hline \multicolumn{7}{|l|}{ Matrix } \\
\hline Total carb veg & & $5 \mathrm{ml}$ & $10 \mathrm{ml}$ & $5 \mathrm{ml}$ & $10 \mathrm{ml}$ & $<5 \mathrm{ml}$ \\
\hline Modern veg & & ++ & +++ & +++ & ++ & ++ \\
\hline Charcoal & Common name & & & & & \\
\hline Betula & Birch & $5(0.05 g)$ & & $4(0.05 g)$ & $6(0.1 g)$ & - \\
\hline Corylus & Hazel & $4(<0.05 \mathrm{~g})$ & $5(<0.05 \mathrm{~g})$ & $12(0.2 \mathrm{~g})$ & $2(0.05 \mathrm{~g})$ & - \\
\hline Ericaceae & Heather family & $7(<0.05 \mathrm{~g})$ & $5(0.05 g)$ & $4(<0.05 g)$ & $3(<0.05 \mathrm{~g})$ & $1(<0.05 \mathrm{~g})$ \\
\hline Maloideae & Rowan type & - & - & - & $1(0.05 g)$ & - \\
\hline$c f$ Maloideae & $c f$ Rowan type & - & $2(0.2 \mathrm{~g})$ & - & - & - \\
\hline Prunoideae & Cherry type & - & $1(<0.05 \mathrm{~g})$ & - & - & - \\
\hline Bark indet & Indet bark & - & - & - & $5(0.1 g)$ & - \\
\hline \multicolumn{7}{|l|}{ Carb macrofossils } \\
\hline Cereal indet & Indet cereal grain & - & - & 2 & - & - \\
\hline Corylus avellana & Hazel nutshell & - & - & - & $2(0.1 \mathrm{~g})$ & - \\
\hline Fucoid seaweed & Seaweed & $1(<0.05 \mathrm{~g})$ & - & - & $1(<0.05 \mathrm{~g})$ & - \\
\hline Hordeum vulgare sl & Six-row barley grain & - & - & - & 1 & - \\
\hline Monocot rhizomes & Grass/sedge rhizome & $2(<0.05 \mathrm{~g})$ & - & - & $7(0.05 \mathrm{~g})$ & - \\
\hline Monocot stems & Grass/sedge stem & - & - & - & $2(<0.05 \mathrm{~g})$ & - \\
\hline Plantago lanceolata & Ribwort plantain seed & - & - & - & - & 1 \\
\hline Polygonum aviculare sl & Knotgrass seed & - & - & - & - & 1 \\
\hline
\end{tabular}




\section{Lithic Material by T Pollard}

Three pieces of struck stone were recovered from the excavation of the Bronze Age cists at Ferndale. One is a small leaf-shaped point or arrowhead and the other two are waste flakes (débitage).

\subsection{Results}

SF2 (Topsoil, context 001) opaque grey flint. Bifacially worked point $(24 \mathrm{~mm} \times 13 \mathrm{~mm} \times 2.5 \mathrm{~mm})$. Quite narrow, 'ogival' form with slightly pronounced shoulders. One leading edge slightly concave. Butt irregularly curved. Very delicate edge trimming, indirect pressure flaking from opposite sides resulting in characteristic ripple effect in edge profile, Neolithic 'leaf shaped-arrowhead' in fine, unrolled condition (surprising given its context) (Illus 4).

SF3 (Fill of cut for cist 010, context 012) chalcedony. Débitage, irregular inner fragment/chunk $(13 \mathrm{~mm}$ $\times 7 \mathrm{~mm} \times 3.5 \mathrm{~mm})$.

SF4 (Mound material, context 014) chalcedony. Débitage, possible core trimming fragment $(17.5 \mathrm{~mm}$ $\times 17 \mathrm{~mm} \times 2.5 \mathrm{~mm}$ ) - from overhanging edge of striking platform, displays vestigial flake/blade removal/edge roughing scars along platform edge.

\subsection{Discussion}

All of the pieces came from secondary contexts within the redeposited soils around and over the cists, although the keen edges and lack of rolling suggest that they have not suffered much in the way of post-depositional abrasion. The leaf-shaped point is small and finely worked, displaying some skill in its manufacture. The very small size is possibly indicative of the scarcity of reasonably sized pebbles of raw material, although there may also be a functional explanation for this. A close parallel is the ogival arrowhead, very slightly smaller in size, from beneath the Bronze Age barrow at Mousland, Stromness (Downes 1994). The two pieces of débitage provide little evidence for period or technology, although the
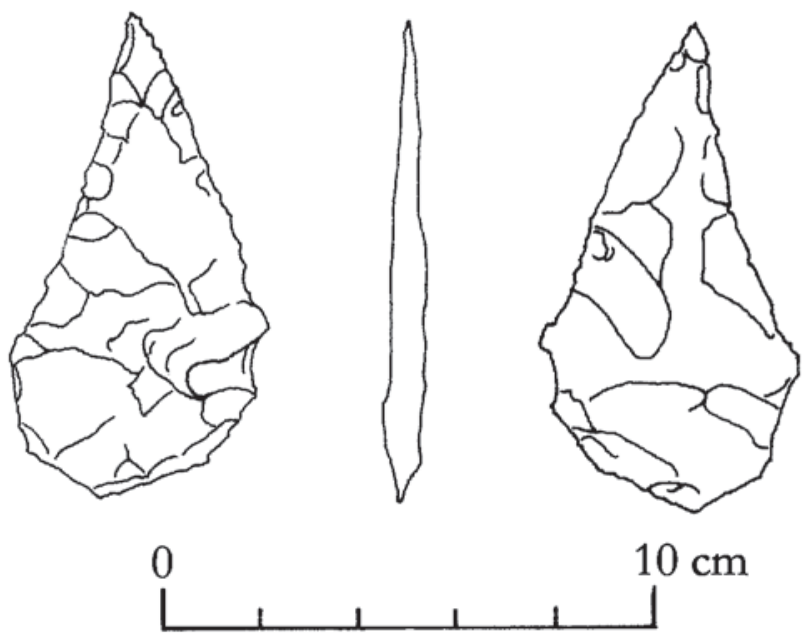

Illus 4 SF2: Leaf-shaped point or arrowhead

possible platform trimming piece does suggest that chalcedony was available in pebbles big enough to create platform cores.

Given their secondary context, it is possible that all of the pieces are contemporary, with the leaf-shaped point giving them a probable early to middle Neolithic provenance. The incorporation of soil deposits containing lithics into later funerary monuments is not unusual, especially in the case of early Neolithic material on Bronze Age burial sites (eg Lelong \& Pollard 1998). During the Bronze Age, the creation of the funerary space and monument quite often appears to have included a deliberate process of redeposition and reincorporating residues of past activity into the ritually controlled domain of the dead, though the motives for this may have varied (Lelong \& Pollard 1998). Keeping this in mind, it seems most likely, especially given their small size, that the deposition of the lithics was an incidental by-product of this process, resulting from the objects being present in soil deposits imported from elsewhere, rather than a deliberate deposition of the lithics themselves. 


\section{Megalithic Art on the Ferndale Slab by G MacGregor}

One of the stones packing the cist slab (004) showed indications of decoration on its surface (Illus 5) during excavation and was retained and brought to Glasgow for closer examination.

The piece is a sub-rectangular (probably) Orcadian sandstone slab, measuring up to $0.59 \mathrm{~m}$ by $0.20 \mathrm{~m}$ by $0.145 \mathrm{~m}$ but with a pronounced prow. The slab shows scars along several edges where it has been roughly flaked to make it more rectangular in form and to emphasize the prow. The end opposite the prow has an area of diffuse picking which appears to relate to modifying the shape of the stone, as opposed to decoration.

Decoration is present on three of the stone's surfaces. On the upper face is a rectangle measuring $0.36 \mathrm{~m}$ by $0.12 \mathrm{~m}$ by $0.16 \mathrm{~m}$ maximum depth. It may have been produced using a pick, analogous to area picking (Shee 1973, 167). On the opposite face to the picked surface are a series of 11 fine incised lines. They have the appearance of a roughly executed series of lozenges or triangles. The third element of decoration is located on the prow itself, where two broad incised lines, up to $0.145 \mathrm{~m}$ by $0.05 \mathrm{~m}$ wide, are present.

The picked rectangle appears to have been traced in outline first and then carved out but not completely finished, as there is a distinctly higher portion at one end. The picking appears relatively fresh in contrast to the fainter, perhaps more weathered incised decoration. It is possible that the incised decoration represents the earliest phase of decoration on the stone, and the pecking may be less weathered in appearance, as it had been undertaken shortly before the slab was utilized for packing the cist.

Both forms of decoration (incised lines and area picking) are found in the tradition of 'megalithic art' (Shee 1973; Eogan 1999). The morphology of the incised decoration on the Ferndale slab can be readily paralleled with decorated stones incorporated at the settlements of Skara Brae (Shepherd 2000) and Barnhouse (Richards 2003) and is also found in the passage tomb at Maes Howe (Bradley 1999). As such, the Ferndale slab may once have been incorporated in a similar later Neolithic structure. The Ferndale slab is notable for having at least two phases of decoration on opposite sides of the stone, meaning that if it once was part of a structure, only one face would have been visible.

Also of note is the outer surface of the stone, which is a light brown colour, whereas the surface of the picked rectangle is a reddish colour. Although there is an increasing awareness that colour played a significant role in the past (Jones \& MacGregor 2002), it is unclear in this case whether the differences were an incidental effect of picking or a meaningful element of production of the picked area.

The incorporation of decorated slabs or stones in the construction of the cist during the late third and early second millennia is well attested and recognized as often having a deliberate significance (Bradley 1992). The significance of the Ferndale slab is difficult to ascertain, but several possibilities are raised by its presence. Its incorporation in the packing stones for the cist could have been completely unintentional and unnoticed by the builders of the cist. Alternatively, it could represent the deliberate reuse of a decorated slab that had been taken from a later Neolithic settlement or passage tomb in the vicinity, evoking meanings relating to the particular site or locale of origin. 

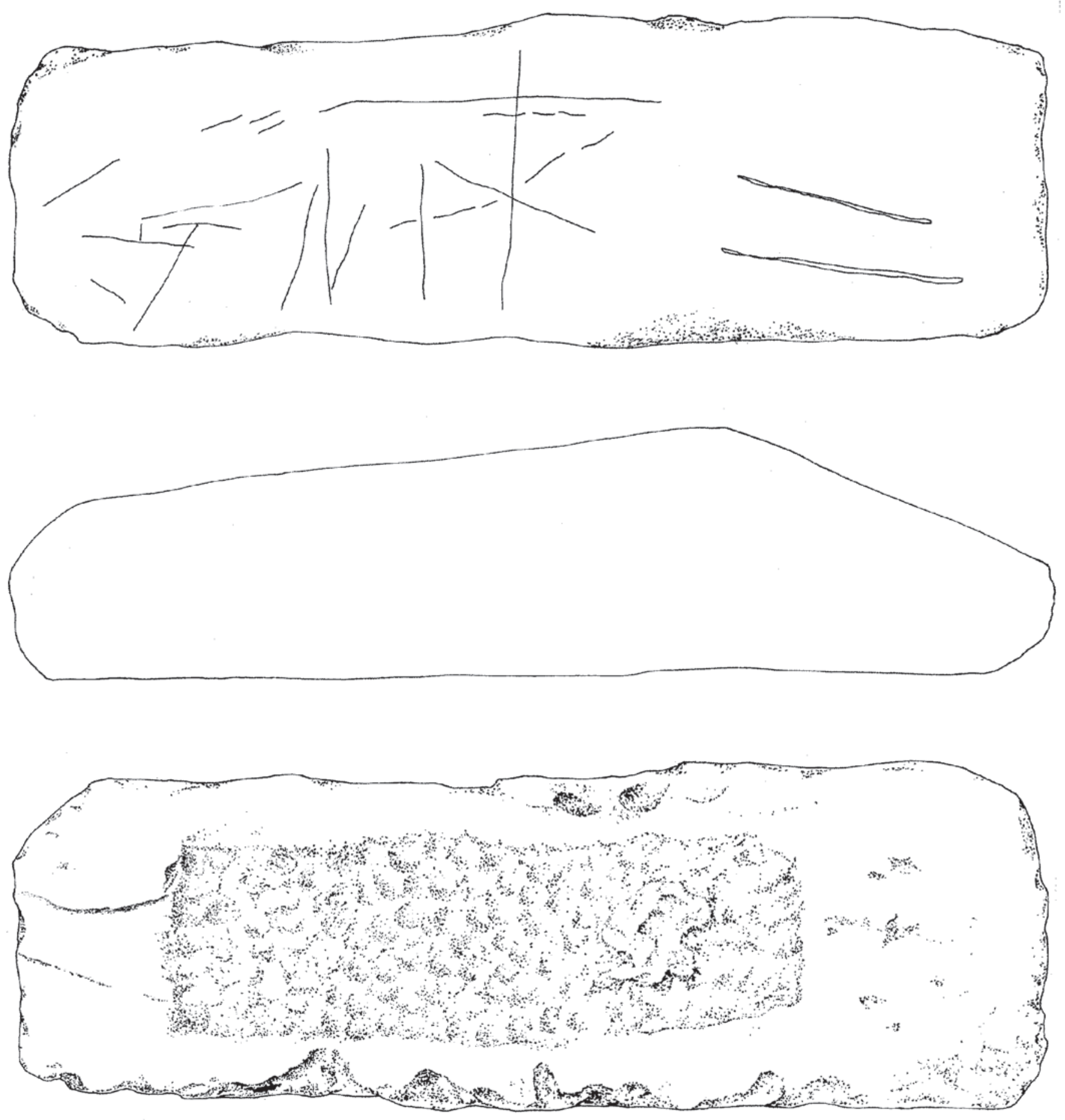

Illus 5 The decorated slab 


\section{Fuel Ash Slag by PRJ Duffy}

A quantity of fuel ash slag (or cramp) was recovered from both cists containing cremations. By far the largest amount was from cist 010, which contained 1140.1g. Cist 004 contained 208.3g, with a further $824.4 \mathrm{~g}$ comprising bone with cramp adhering to the surface of the cremated material. Cist 003 was found to contain $1.1 \mathrm{~g}$ of this material. It is probable, given the machine truncation across site, that the material from the latter cist is present as a result of machine action.

The association of fuel ash slag with cremated bone is one that is often found in cremation deposits of this date (eg Downes 1995). The nature of this material remains enigmatic and is still not fully understood. Recent excavations in Orkney have led to an Historic Scotland-funded analysis of this material in an attempt to resolve the question of its origin (see Ballin Smith, in prep); further discussion of the subject is underway (Photos-Jones et al, in prep). Accordingly, analysis of the material from Ferndale was not undertaken at this time. 


\section{Radiocarbon Dates from Ferndale by PRJ Duffy}

Two samples of single-element cremated human bone, one each from cist fills (contexts 006 and 008), were sent for accelerator dating at the Scottish Universities Research and Reactor Centre (Table 2). A calibrated date of 1980-1760 BC (SUERC-2987) from context 006 and a calibrated date of 1980-1740 BC (SUERC-2988) from context 008 was obtained at a 2 -sigma level of confidence. The dates were calibrated on OxCal v3.8. Human bone submitted to obtain a date from the fill of cist 003 was found to be insufficiently well-preserved to allow a date to be obtained.

The dated material points to a secure date in the first quarter of the second millennium BC. This would appear to fit broadly with the limited dating evidence available from cists containing cremations in Orkney, although the site would appear to be amongst the earlier examples in this tradition (see Table 3, below)

Table 2 Radiocarbon dates from Ferndale

\begin{tabular}{|c|c|c|c|c|c|}
\hline \multirow[b]{2}{*}{ Lab code } & \multirow[b]{2}{*}{ Sample material } & \multirow[b]{2}{*}{ Lab age $B P$} & \multicolumn{3}{|c|}{ Calibrated dates } \\
\hline & & & $\delta^{13} \mathbf{C}$ & $1 \sigma$ & $2 \sigma$ \\
\hline $\begin{array}{l}\text { SUERC-2987 } \\
(\text { GU-12120) }\end{array}$ & $\begin{array}{l}\text { Cist } 010 \text { (context 006) } \\
\text { Cremated human femur }\end{array}$ & $3555 \pm 35$ & $-23.8 \%$ & $1950-1770 \mathrm{BC}$ & $2020-1760 \mathrm{BC}$ \\
\hline $\begin{array}{l}\text { SUERC-2988 } \\
(\text { GU-12121) }\end{array}$ & $\begin{array}{l}\text { Cist } 004 \text { (context 008) } \\
\text { Cremated human humerus }\end{array}$ & $3550 \pm 35$ & $-25.3 \%$ & $1950-1770$ вС & $2020-1740$ вС \\
\hline
\end{tabular}




\section{Discussion by PRJ Duffy}

The excavations at Ferndale have identified a complex of three cists, two of which were securely associated with a barrow and contained cremated human remains. Dates obtained from cremated bone from these cists demonstrate that the occupants of the cists died in the first quarter of the second millennium BC; as such, the mound and cists fit into an increasingly well-defined Orcadian tradition of cist burials covered by artificial mounds, although this is an apparently early example (see Table 3 ). The third cist differs in several important respects from the other two cists at the site, and indeed from the majority of excavated cists in Orkney. Similarities can, however, be seen with the cists in pits excavated at Crantit and Kewing (Ballin Smith, in prep). These sites can also be seen as bearing broad morphological similarities to the larger rock-cut cist at Sand Fiold (Dalland 1999).

\subsection{The Bronze Age cists and mound}

Erosion and disturbance by both human and animal agency have, in many instances, been the implicit factors in the modern motivations to excavate similar mound sites throughout the region (eg Downes 1995). In some respects, this could almost be added as a defining characteristic of published modern archaeological investigations of this type of monument. The site at Ferndale is no exception, and recovery of information and by inference the postexcavation analysis and interpretations of the site have been frustrated by the circumstances of discovery. Here the unintentional disturbance was the result of a modern JCB excavator bucket, which removed large swathes of soil. Ironically, this action promoted the identification of the anthropogenic nature of the mound and simultaneously obscured interpretation of key constructional features and stratigraphic relationships from the physical evidence. Despite the truncated nature of much of the archaeological strata on the site, however, enough evidence has survived to draw parallels with excavated examples from the region and to understand the site within the tradition of Orcadian barrows.

Numerous such mounds and groups of mounds are recorded throughout the Orkney Islands and are estimated to number in hundreds if not thousands (Downes 1994). The focus of investigation since the early 19th century (eg Traill 1876; Watt 1885), such sites are often devoid of readily datable evidence. It is only more recently that scientific investigation has begun to refine and redefine the nuances of construction use and dating beyond typological comparisons of architectural style and limited artefactual evidence (Hedges 1980; Moore \& Wilson 1995). Current thought suggests two distinctive classes of cist burials are widespread: flat, short cists often inserted into a natural rise or mound; and artificial mounds with cists (Moore \& Wilson 1995). Despite the problems of truncation (see below) at Ferndale, the site can clearly be seen as belonging to the latter of these groups: a 'ditchless, scrape barrow' (Hedges 1977,141 ), albeit with some variation. It is not clear whether the mound is an isolated example or belongs to a barrow cemetery, such as that at Summers Dale (HY31SW 150). Three 'tumulii' are, however, present to the south-west of the site at Blubbersdale (HY32SE 14) and a single barrow is reported to the east at Castle (HY32SE 2). The barrow cemetery of Gitterpitten (HY32SE 8) also lies to the east. It is possible that further barrows remain undiscovered

Table 3 Summary of radiocarbon dates from cists in Orkney containing cremations

\begin{tabular}{llllll}
\hline Lab code & Site & Material & Context & Lab age BP & Reference \\
\hline SUERC-840 & Riff & Cremated bone & Cist fill & $3570 \pm 45$ & Downes in Discovery Excav Scot 2003 \\
SUERC-2987 & Ferndale & Cremated bone & Cist fill & $3555 \pm 35$ & This paper \\
SUERC-2988 & Ferndale & Cremated bone & Cist fill & $3550 \pm 35$ & This paper \\
SUERC-817 & Kewing & Cremated bone & Cist fill & $3520 \pm 45$ & Ballin Smith Discovery Excav Scot 2003 \\
SUERC-815 & Crantit & Cremated bone & West cist fill & $3460 \pm 45$ & Ballin Smith in Discovery Excav Scot 2003 \\
SUERC-844 & Gitterpitten & Cremated bone & Cist fill & $3430 \pm 45$ & Downes in Discovery Excav Scot 2003 \\
SUERC-816 & Crantit & Cremated bone & West cist fill & $3420 \pm 50$ & Ballin Smith in Discovery Excav Scot 2003 \\
GU-3186 & Mousland & Birch charcoal & Cist fill & $3400 \pm 100$ & Downes 1994 \\
AA-53155 & Gitterpitten & Willow charcoal & Cist fill & $3315 \pm 40$ & Downes in Discovery Excav Scot 2003 \\
SUERC-839 & Varme Dale & Cremated bone & Cist fill & $3280 \pm 45$ & Downes in Discovery Excav Scot 2003 \\
SUERC-837 & Varme Dale & Cremated bone & Cist fill & $3125 \pm 45$ & Downes in Discovery Excav Scot 2003 \\
AA-53156 & Gitterpitten & Willow charcoal & Cist fill & $2995 \pm 40$ & Downes in Discovery Excav Scot 2003 \\
\hline
\end{tabular}


in the immediate vicinity. More generally, it is clear that the site forms part of a wider local landscape of barrow cemeteries.

Of the three cists excavated on site, two (cists 004 and 010) contained cremated bone and were associated with remnant mound material (context 014). The stratigraphic relationship between these two cists could not be discerned from excavation, and only the base slab and a small part of the northern side of the latter cist remained, precluding any discussion as to architectural differences in construction. One important difference was, however, noted: cist 004 had a number of packing stones surrounding the flat cist uprights, whilst the sides of cist 010 appeared to have sat flush against the mound material. A partial clay lining was also present in cist 004, sealing the base slab to the sides. The original observed differences in cist construction had led to the preliminary interpretation of cist 010 as the primary burial on site, with cist 004 a later construction placed in a cut (021) excavated into the mound body and packed with stones.

In considering the phasing of the site, it is of value to consider the wider evidence for phasing on similar sites. It is apparent from excavated examples that construction of this type of monument was a ritual process focused primarily on the cist burial, followed by a phase of covering the cist and its contents with mound material. Evidence from several sites shows the primary cist would have been constructed as a freestanding structure on the ground surface or in a shallow scoop, its position maintained by rough corbelling or support slabs. Often a kerb of stones was constructed at around the same time, delineating the area of focus. Earth, gravel and stones would then be piled over the cist to create the artificial mound (see for example Ashmore 1974). In cases where secondary cists exist, this later phase is generally carried out in the same way, with the cist constructed first and coverage by mound material second (see for example Downes 1995).

Utilizing these parallels, it is clear that cist 004, with its stone packing around it, is highly reminiscent of primary cist constructions found at other sites and almost certainly represents the primary focus of the mound construction. Given the short distance between the two cists (only $0.6 \mathrm{~m}$ ), and the machine truncation of the mound deposits, it is not certain whether the mound creation was phased or a single event. It may be that both cists were covered at the same time, an unusual construction process in Orcadian barrows. Alternatively, some of the mound material may have been removed to allow the construction and secondary covering of this cist. The radiocarbon dates from the cremated human remains do, however, suggest that the construction of both cists was broadly contemporary and is likely to have happened within a generation. The precise nature of the construction phasing aside, it is probable that cist 010 is a secondary cist burial within the mound body, a feature readily paralleled at Trumland (Craw 1934), Linga Fold 5, Linga Fold 8 (Downes 1995) and Linga Fold 9 (Moore \& Wilson 1995).

These specific actions at artificial mound sites contrast interestingly with the other dominant type of Orcadian cist burial where flat, short cists are inserted into the existing ground surface by means of a cut that is subsequently backfilled, such as at Lower Ellibister (Hedges 1980). Other commentators have noted the conscious transformation of landscape as a result of the creation of artificial mounds (see Downes 1994), but little consideration has been given to the psychological distinction between covering the dead with a monumental construction and the insertion of the dead into a pre-existing feature, be it artificial or natural. Whether this represents a chronological shift, social distinction or otherwise can only be explored through more detailed research, but it is of interest to note here that the variation exists.

Given the identification of cist 004 as the primary cist burial of this phase, the worked stone (Illus 5) from the supporting stones becomes intriguing. The use of the stone cannot be discounted as an entirely unconscious addition to the cist support. The incised and pecked decoration is similar to that seen at a variety of Neolithic sites in Orkney, suggesting the piece is of this date or earlier. The motif of reused Neolithic material in Bronze Age tombs is one that is familiar from a number of Orcadian sites, most notably Mousland (Downes 1995), where the leafshaped arrowhead found in the topsoil at Ferndale also finds ready parallel. Given this wider tradition, the presence of an unrolled arrowhead and stone displaying parallels with Neolithic art within the Ferndale barrow is an interesting and perhaps not entirely coincidental feature.

Contained within the cists were quantities of cremated human bone. Analysis of the remains demonstrated that cist 004 contained the remains of three individuals: an older adult male, a young adult female and an infant of around 15 months. The male individual had been suffering from a well-developed and undoubtedly painful dental abscess and a bone infection of the femur. The female was suffering from mild iron deficiency anaemia. Cist 010 held the more poorly preserved remains of an adult of unidentified sex. Comparison with assemblages from similar sites is frustrated by limited published skeletal data and the absence of any synthesis of cremated skeletal material from Orcadian cists. The preponderance of non-adults in many of the human remains assemblages from barrows has been noted previously (Hedges 1977), but evidence from Queenafjold (Ritchie \& Ritchie 1974) and the unpublished material from the Knowes of Trotty (Julie Roberts, pers comm) suggests that that this is a trend, rather than a defining characteristic. The human remains assemblage from Ferndale must thus await the analysis and publication of further material before its significance can be addressed in any meaningful context. 


\subsection{The rock-cut cist}

To the west of the Bronze Age cists lay a further cist (003), quite dissimilar in form and appearance to those discussed above. The cist was positioned in a large, rock-cut pit and contrasted with the simpler 'cist in mound' construction of the other cists. This pit was significantly larger than would be required for functional access for construction, and contrasts with the majority of flat cists excavated on Orkney. These are generally only large enough to take the cist, and are cut into subsoil, as exemplified at Lower Ellibister (Hedges 1980) and Midskaill (Moore \& Wilson 1995). More significantly, the cist was flanked on its western side by two parallel rows of dry-stone walling, between 0.5 and $0.75 \mathrm{~m}$ in length and up to three courses in height. This walling appears to have formed a rough stance or passage at the western side of the cist, and would seem to be an overelaboration if intended to be purely for cist support. In further contrast, the cist contained an inhumation rather than a cremation; observations in excavation suggest that these remains may also have been disarticulated. No evidence of superstructure or burial marker was found.

The differences in this cist morphology are striking, and it is a matter of regret that no stratigraphic relationship between the artificial mound and the cist was preserved. The lack of date from the poorly preserved remains is similarly frustrating. It seems unlikely, however, that the cist is a secondary burial as part of the mound, given the care taken in its construction, the burial rite utilized and its subterranean position. Nor, considering wider Orcadian parallels (see above), can it be considered a primary burial of the mound construction phase. Given this, we are left with the possibility that the cist relates to a different phase of burial activity, and may even have acted as an initial reason for the location of the artificial mound and the associated cists in the area.

In examining potential parallels to help clarify the chronological relationship between these two potential site phases, it is of note that few Orcadian cists have morphological and architectural resonance with that found at Ferndale. Five main morphological features mark the cist as different from the other two on site:
- the large rock-cut pit

- the subterranean cist

- the dry-stone construction within the pit

- the inhumed burial

- the lack of superstructure marking the burial.

Parallels with these features can be found from the south-east cist at Crantit (Ballin Smith, in prep) where a large pit was excavated through subsoil to contain a subterranean cist supported by dry-stone walls. Within the cist, the remains of a badly decayed inhumation were present. No date was obtained from the poorly preserved inhumation.

At Kewing, Rendall (Ballin Smith, in prep), a similar, larger pit was partially excavated into bedrock to contain a wholly subterranean cist supported with dry-stone masonry. In this instance, however, the burial contained within was a cremation. The site was dated from cremated bone to $3520 \pm 45 \mathrm{BP}$, which is broadly contemporary with the cremations from Ferndale (see Table 3). The suggestion of the excavator that this cist may have been designed for the deposition of additional burials is, however, intriguing. Given the poorly preserved nature of the inhumations from Ferndale and Crantit, it may be that the Kewing tomb was originally designed to receive a since-decayed inhumation burial and that the dated cremation is a later deposit.

One further parallel exists from Orkney that combines several of the distinctive elements described above. The site of Sand Fiold was a large, rock-cut pit containing a subterranean cist supported by elements of dry-stone walling (Dalland 1999). The cist had been reused for interment several times and contained a number of burials, dated from $4100 \pm 50$ BP to $3530 \pm 40 \mathrm{BP}$, although these dates and the excavation data did not allow a final statement to be made as to the chronology of the site. Although significantly larger, and of superior construction to the examples described above, it is of potential significance that Sand Fiold shares particular characteristics with Ferndale, Crantit south-east and Kewing that distinguishes them from the more readily identifiable flat cist and 'cist in mound' style of cist burial in Orkney. 


\section{Conclusions}

In conclusion, and despite the truncation of deposits that had occurred at the site, utilizing excavation data, dating evidence and parallels from other Orcadian barrow sites, it is possible to offer three reconstructions of the overall chronology of the site:

Interpretation 1 - The primary burial on site was an inhumation contained within the large rock-cut cist. Subsequently, a typical freestanding cist containing a cremation was constructed on the site and covered by an artificial mound. A secondary cist burial also containing a cremation was constructed at this time or shortly afterwards and also covered by mound material.

Interpretation 2 - The rock-cut cist and the cists within the mound are broadly contemporary. The mound cists were constructed as described above, and the rock-cut cist constructed to the western side.

Interpretation $\mathbf{3}$ - The mound cists were constructed on the site as described above. The rock-cut cist is a later addition to the site.

Each of these scenarios offers its own potential importance to the understanding of the cist-building traditions in Orkney, but at present none can be fully substantiated from the excavation results from the site, or from wider Orcadian parallels. What is clear is that the cist burial tradition in the islands is both complex and only partially understood at present. It would appear, however, that on morphological grounds a previously unidentified tradition may be emerging from recently excavated sites in the islands, which I have termed the 'pit cist'. As has been demonstrated, these subterranean pit cists are distinct in several ways to the better documented 'mound and cist' and flat cist traditions, and would appear to represent an alternative way of interring the dead - structurally, psychologically and symbolically. The main morphological traits can be seen as the:
- presence of a large pit, often rock-cut

- insertion of a cist, reinforced, supported or enhanced by elements of dry-stone walling

- subterranean nature of the cist

- frequent presence of an inhumation burial

- lack of visible superstructure.

These traits echo the architectural features of many of the Neolithic tombs throughout the islands, and pit cists may indeed prove to have a Neolithic origin. Variations among sites apply, in common with other Orcadian cist traditions, but are likely to reflect local preference or reaction to particular local circumstances. These basic morphological differences remain the same.

It is tempting to suggest at Ferndale that the pit cist is the earliest burial on site, possibly Neolithic, which provided a focus for a later barrow. In this light, the site could be seen as demonstrating the symbolic reuse not only of earlier material culture, but also place and landscape. Perhaps such pit cists represent a crossover point between old and new ways of social organization and treatment of the dead; between the passage tombs and chambered cairns of the Neolithic and the flat cists and cists within mounds of the Bronze Age; between earlier inhumation practices and later preferences for cremation. Given the longevity of use and changes in burial practice potentially demonstrated at Sand Fiold, this is indeed a tempting suggestion. At present, however, based on the excavation data from Ferndale and the wider parallels that exist, such an observation can only be speculation. It is hoped that further synthetic research on excavated examples and refinement of dating evidence from as yet unexcavated and undiscovered sites may help, in time, to resolve their true significance and the place of Ferndale within the Orcadian cist burial tradition. 


\section{Acknowledgements}

The fieldwork was undertaken with the assistance of Judith Robertson. The excavators would also like to thank Julie Gibson and Jane Downes of the Orkney Archaeological Trust for their help and advice, and Mr Stevie Nicholson for permission to excavate on the land.

The project was specified and funded through to publication by Historic Scotland. The project was monitored by Patrick Ashmore for Historic Scotland. The project was managed for GUARD by Gavin MacGregor and Julie Roberts. Initial copyediting was by Olivia Lelong. Comments on draft versions of this paper by all are gratefully acknowledged. 


\section{References}

Ashmore, P J 1974 'Excavations at Summersdale, Orkney by F G Wainwright in July 1960', Proc Soc Antiq Scot 105, 41-2.

Aufterheide, A C \& Rodriguez-Martin, C 1998 The Cambridge Encyclopedia of Human Paleopathology. Cambridge.

Beijerinck, W 1947 Zadenatlas der Nederlandsche Flora. Wageningen.

Ballin Smith, B (in prep) 'Crantit, Nether Onston and Kewing: The end of the old and the beginning of the new'.

Bradley, R 1992 'Turning the world: rock carvings and the archaeology of death' in Sharples, N \& Sheridan, A (eds) Vessels for the Ancestors, 168-76. Edinburgh.

Bradley, R 1999 'Discovering decorated tombs in Neolithic Orkney', Curr Archaeol 14(5), 184-7.

Craw, J H 1934 'A mound containing short cists at Thrumland, Rousay, Orkney', Proc Soc Antiq Scot 68 (1934), 68-70.

Dalland, M 1999 'Sand Fiold: the excavation of an exceptional cist in Orkney', Proc Prehistoric Soc 65, 373-413.

Discovery Excav Scot 2003 'A list of archaeological radiocarbon dates' compiled by Ashmore, P J. Edinburgh.

Dickson, C A \& Dickson, J H 2000 Plants and People in Ancient Scotland. Stroud.

Downes, J 1994 'Excavation of a Bronze Age burial at Mousland, Stromness, Orkney', Proc Soc Antiq Scot 124, 141-54.

Downes, J (with MacGregor, G) 1995 Linga Fold, Sandwick, Orkney. GUARD Unpublished Data Structures Report. Glasgow.

Eogan, G 1999 'Megalithic art and society', Proc Prehistoric Soc 65, 415-46.

Hedges, M E 1977 'The excavation of the Knowes of Quoyscottie, Orkney: a cemetery of the first millenium BC', Proc Soc Antiq Scot 108 (19767), 130-56.

Hedges, J W 1980 'Short cists recently excavated at Lower Ellibister and other locations in Orkney', Proc Soc Antiq Scot 110 (1978-80), 44-71.

Holden, J L, Phakey, P \& Clement, J G 1995 'Scanning electron microscope observations of heat-treated human bone', Forensic Science International 74, 29-45.

Jones, A \& MacGregor, G 2002 Colouring the Past: the Significance of Colour in Archaeological Research. Berg.

Lelong, O \& Pollard, T 1998 'Excavation of a Bronze Age ring-cairn at Cloburn Quarry, Cairngryffe Hill, Lanarkshire', Proc Soc Antiq Scot 128, 105-42.
Moorress, C F A, Fanning, E \& Hunt, E E 1963 'Age variation of formation stages for ten permanent teeth', Journal of Dental Research 42(6), 1490-502.

Moore, H \& Wilson, G 1995 “ Two Orcadian cist burials: excavations at Midskaill and Linga Fold, Sandwick', Proc Soc Antiq Scot 125, 237 51.

McKinley J I 1993 'Bone fragment size and weights of bone from modern British cremations and the implications for the interpretation of archaeological cremations', International Journal of Osteoarchaeology 3, 283-7.

Photos-Jones, E, Hall, A J, Jones, R E \& Ballin Smith, B in prep 'The cramp of the living and the cramp of the dead: vitrified fuel waste as a monitor of diet, industry and ritual'.

Richards, C 2003 Dwelling Among the Monuments: an Examination of the Neolithic Village of Barnhouse, Maeshowe Passage Grave and Surrounding Monuments at Stenness, Orkney. Cambridge.

Ritchie, G \& Ritchie, A 1974 'Excavations of a barrow at Queenafjold, Twatt, Orkney', Proc Soc Antiq Scot 105 (1972-4), 33-42.

Schweingruber, F H 1990 Anatomy of European Woods. Berne \& Stuttgart.

Shipman, P, Foster, G \& Schoeninger, M 1984 Burnt bones and teeth: an experimental study of colour, morphology, crystal structure and shrinkage. J Archaeol Sci 11, 307-25.

Shee, E A 1973 'Techniques of Irish passage grave art' in Daniel, G \& Kjaerum, P (eds) Megalithic Graves and Ritual, 163-72. Jutland.

Shepherd, A 2000 'Skara Brae: expressing identity in a Neolithic community' in Ritchie, A (ed) Neolithic Orkney in its European Context, 13958. Cambridge.

Stace, C 1997 New Flora of the British Isles, 2nd Edn. Cambridge.

Stuart Macadam P S 1992 'Porotic hyperostosis: a new perspective', Am J Physical Anthropol 87, $39-47$.

Triall, W 1876 'Notice of two cists on the farm of Antabreck, North Ronaldsay, Orkney', Proc Soc Antiq Scot 11 (1876), 309-10.

Twohig, E S 1981 The Megalithic Art of Western Europe. Oxford.

Ubelaker D H 1989 Human Skeletal Remains Excavation, Analysis, Interpretation, 2nd Edn. Washington.

Watt, W G T 1885 'Notice of two cists with urns of steatite in the parish of Sandwick, Orkney', Proc Soc Antiq Scot 19 (1885), 160-1. 